\title{
THE ROLE OF SUPPLEMENTAL IRRIGATION TO CROP WATER USE UNDER RAINWATER HARVESTING
}

\author{
O PAPEL DA IRRIGAÇÃO SUPLEMENTAR NA REDUÇÃO DO USO DA ÁGUA \\ ATRAVÉS DA CAPTAÇÃO DE ÁGUAS PLUVIAIS
}

\author{
Abubaker B ALI' ${ }^{1}$;i HONG ${ }^{1}$; Nazar ELSHAIKH ${ }^{2}$; Yan HAOFANG ${ }^{1}$ \\ 1. Research Center of Fluid Machinery \& Engineering, National Research Center of Pumps, Key Lab of Water Saving Irrigation, \\ Jiangsu University, Zhenjiang, China, 212013; 2. State Key Laboratory of Efficient Irrigation-Drainage and Agricultural Soil-Water \\ Environment, College of Water Conservancy and Hydropower, Hohai University, Nanjing, 210098, China.
}

\begin{abstract}
Sorghum is an important food and dominant multi-purpose cereal crop in Sudan. Its production influenced by plant available soil water content at planting and growing season rainfall. Series of field experiments were carried-out to study the sorghum water use potentiality using different water harvesting techniques (WHT) and supplemental irrigation (SI). Soil moisture content (SMC), grain yield and water use efficiency (WUE) of sorghum were calculated during the years of 2012 and 2013. The results showed that the WHT and SI affected the SMC, growth and productivity parameters of sorghum. The results were also indicated that, the tied-ridging with $\mathrm{SI}\left(\mathrm{T} 1_{\mathrm{w}}\right)$ produced the highest values of SMC, sorghum productivity and WUE $\left(10.59 \%, 3850 \mathrm{~kg} \mathrm{ha}^{-1}\right.$, and $0.71 \mathrm{~kg} \mathrm{~m}^{-3}$ in season 2012 , respectively. Whereas in season 2013 the values were $11 \%, 4760 \mathrm{~kg} \mathrm{ha}^{-1}$ and $0.86 \mathrm{~kg} \mathrm{~m}^{-3}$ with the same arrangement mentioned above. Conclusively, the WUE could be promoted by implementing WHT as water stewardship. Nevertheless SI should consider as pivot factor that compensate the shortage in the rainwater.
\end{abstract}

KEYWORDS: Sorghum. Water harvesting. Water use efficiency.

\section{INTRODUCTION}

The main factor that subjecting crop productivity in arid and semi-arid regions worldwide is water deficit. The total crop yield and yield productivity in rain-fed sector is far behind its potential in Sudan which makes it unsustainable, that referred to erratic rainfall, alteration and soil deterioration (AYOUB, 1999). Sorghum plays a vital role in the food security in Sudan, and it also considered one of the most economic important cereals (FAO, 2000). It is grown in a wide rainfed areas estimated by 15 million ha under a different soil and climatic conditions, covering at least onethird of the total cropped area where it produce about $75 \%$ of food grains in the country.

In Western Sudan, its production influenced by available soil water content at planting and growing during rainfall season (AHMED; NAGGAR, 2003). Therefore, there is an urgent needs for proper water and soil management in order to ensure sustainable food production represented in sorghum crop since it is the main food for the majority of developing countries population as well as Sudanese.

In-situ rainwater harvesting was suggested to solve the problem of water deficiency which associated with rainfall hesitation (HASSAN et al., 2012). Rainwater harvesting has the potential to prevent soil erosion, water shortage and improve crop productivity when companied with supplementary irrigation (SI) (SALEM et al., 2014; JIANG et al., 2013). Rain water harvesting (RWH) term was used to describe the collection and concentration of runoff for many uses, including agricultural and domestic use (SALEM et al., 2014).

WHT has been widely used and has been extended to water-stressed regions around the world for domestic use and SI for improving cultural production in many countries such as China, Brazil, Australia, Germany, India, Japan, New Zealand (JIANG et al, 2013). Also, many researches have been carried out in the Middle East region well as in Syria (OWEIS; HACHUM, 2012). However, Land preparation whereby the top soil is plowed and concentrated known as ridge tillage. With proper construction all WHT practices (tied-ridging, ridging and basin) could decrease surface runoff and increase retained water within the field. Hence, the in-situ RWH such as ridging (R) is one of the most popular soil water conservation practice and widely used methods of land preparation through which seedbed is produced in surface soil for planting or seeding crops. As mentioned by Hulugalle (1990), tied-ridges (TR) are open ridges to which short earthen dikes are constructed, at right angles, at intervals of 1-2 meters. Many studies (HULUGALLE 1990; ALI et al, 2016) confirmed that tied-ridging systems were effective technique for water conserving. Mudatenguha et al, 2014, reported that this techniques ridging and tied-ridging used for grain yield worldwide in Ethiopia and 
Rwanda. Moreover, plants grow in one or more rows per ridge, crops could be grown in the furrows to make advantage of the wetter condition of the soil.

Furthermore, the low cost of WHT makes it feasible for everyone, particularly for poor traditional farmers and are more effective practice in sub-Saharan Africa (SSA) (MUDATENGUHA et al, 2014). Rainwater harvesting is easier to develop compared to other water resources and it can be easily integrated with SI system when there is water deficit during crop growth stages where it stabilizes the yield as suggested in arid and semi-arid conditions specifically in western Sudan. Thus, application and regionalization of WHT is expected to provide water for two main sectors i.e. irrigation (quantity) and domestic use (quality), reduce crop yield fluctuation, reduce risk of investment in rainfed sector, promote meadows, decrease use of groundwater in agriculture, save soil fertility, and increase groundwater recharge (SCHEIERLING et al., 2012). Several studies have showed a positive response of crops to SI under rain-fed for the purpose of increase crop yield by more than $30 \%$, and water use efficiency (WUE) ranged from 0.7 to $5.7 \mathrm{~kg} \mathrm{~m}^{-3}$ for wheat, corn and flax, and $30-40 \mathrm{~kg} \mathrm{~m}^{-}$ ${ }^{3}$ for vegetables (JIANG et al., 2013).

Combining RWH and SI will enhance WUE as well as water management, especially rainwater, resulted in the mitigation of the water shortages and maximum of the socio-economic. Hence, this work was aimed to study the potentiality of different
WHT with SI and their effect on sorghum water use, in North Kordofan State (NKS).

\section{MATERIAL AND METHODS}

\section{Field Scope}

In this work a field trial was carried out during two consecutive rainy seasons in 2012 and 2013 at North Kordofan State (NKS), Western Sudan (latitude $12^{\circ} 13^{\prime} \mathrm{N}$ to $14^{\circ} 20^{\prime}$ and longitude $29^{\circ} 30^{\prime}$ to $28^{\circ} 10^{\prime} \mathrm{E}$ ). The climate of the study area is characterized as arid and semi-arid with a short rainy season (July to October) and high evaporation. The meteorological data at the experimental site includes mean monthly relative humidity, temperature, and rainfall recorded during two rainy seasons and a long term average meteorological data from (30 years) (Figure 1) and physical and chemical properties are reported in (Table 1). Figure 1 show the monthly means of relative humidity, temperature and rainfall records during the two seasons and the average of the climatic data (19712010), respectively. The highest relative humidity value was $78 \%$ recoded in 2013 followed by $65 \%$ recorded in 2012 and $48 \%$ recorded for the period (1971-2010). The lowest value of relative humidity was $31 \%$ recorded in October 1971-2010. The highest value of the mean temperature was $34.5^{\circ} \mathrm{C}$ recorded in 2012 for July whereas, the lowest value of the mean temperature was $30.2{ }^{\circ} \mathrm{C}$ recorded in 2013 for August. The rainfall data showed that the largest amount of rain fall was received in August.

Table 1. Soil physical and chemical characteristics of the study area.

\begin{tabular}{cc}
\hline Prosperities & Average \\
\hline Sand \% & 69 \\
Silt \% & 11 \\
Clay \% & 20 \\
Bulk density $\left(\mathrm{g} \mathrm{cm}^{-3}\right)$ & 1.5 \\
Water holding capacity $\left(\mathrm{mm} \mathrm{m}^{-1}\right)$ & 27 \\
Hydraulic conductivity $\left(\mathrm{mm} \mathrm{hr}^{-1}\right)$ & 4 \\
Nitrogen $(\%)$ & 0.05 \\
Phosphorous $\left(\mathrm{mg} \mathrm{l}^{-1}\right)$ & 3.4 \\
Potassium (mmol $\left.\mathrm{L} \mathrm{L}^{-1}\right)$ & 0.11 \\
Organic matter $(\%)$ & 1.2 \\
$\mathrm{pH}$ & 7.04 \\
\hline
\end{tabular}



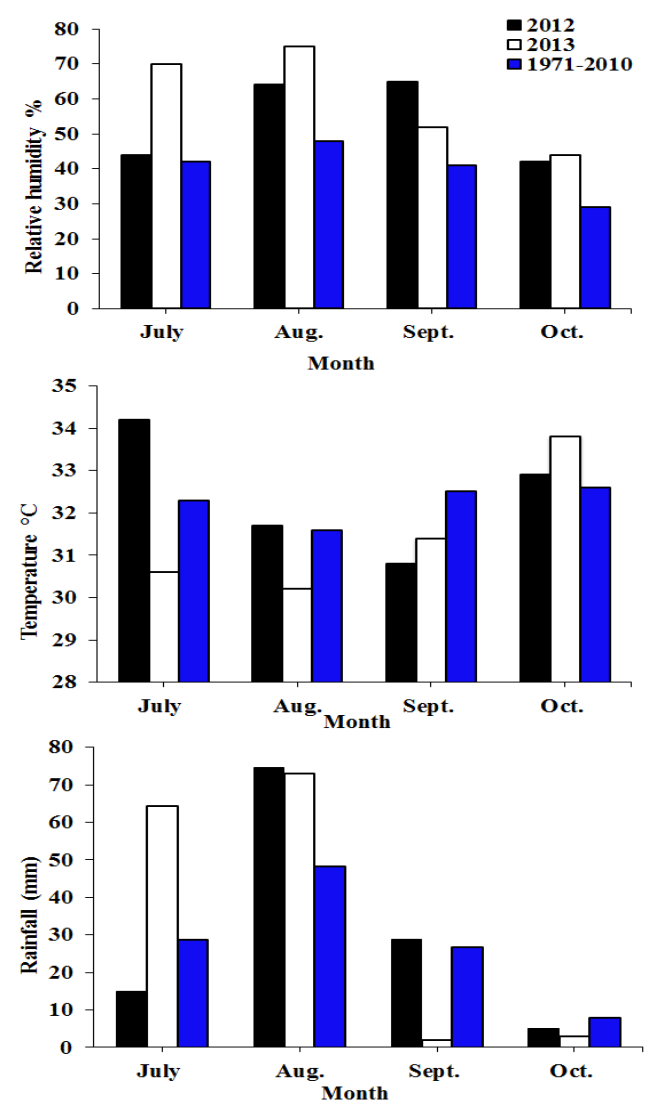

Figure 1. Mean climatic data of the study area.

To investigate the effect of the supplemental irrigation (SI) along with water harvesting techniques (WHT) on sorghum production, three WHT were used namely: tied-ridging, ridging, basin and prevailing farming culture as control treatment. The experiment was carried out in an area of 3266 $\mathrm{m}^{2}$ with homogenous soil texture and uniform slope. The study was organized in split design with two main blocks replicated three times where SI were assigned plots each of them contained eight sub plots where WHS treatments were assigned. Each plot occupied area of $90 \mathrm{~m}^{2}$ across the slope with 2 $\mathrm{m}$ spacing between subplots in the vertical direction and $1 \mathrm{~m}$ in the horizontal direction. Additional $1 \mathrm{~m}$ spacing between different replication kept as isolation distance and for waterways.

\section{Spatial Water Harvesting Techniques and Supplemental Irrigation}

The spatial WHT are: Ridging (R) were raised $0.2 \mathrm{~m}$ with base width of $0.3 \mathrm{~m}$ and $1.3 \mathrm{~m}$ apart. Tied-ridging (T): Lower ridge (cross-ties) $0.15 \mathrm{~m}$ high, $0.3 \mathrm{~m}$ at the base and $1.5 \mathrm{~m}$ apart were constructed with hoes across the aforementioned ridges thus creating mini-basins. Basin (B): Each plot was divided into three equal basins with, $0.2 \mathrm{~m}$ of ridge height. Control (C): These plots were left flat to represent the conventional field practice as adopted by the local farmers (Figure 2). In SI treatments, each replication was divided into two sections; one section was only rain-fed while the other was supplemented with a predetermined amount of irrigation water from a raised water tank. The depth of SI was calculated by subtracting the effective rainfall $(0.70$ of rainfall) from the crop evapotranspiration and applied to each plot at an irrigation interval of eight days as description by Allen et al. (1998). 


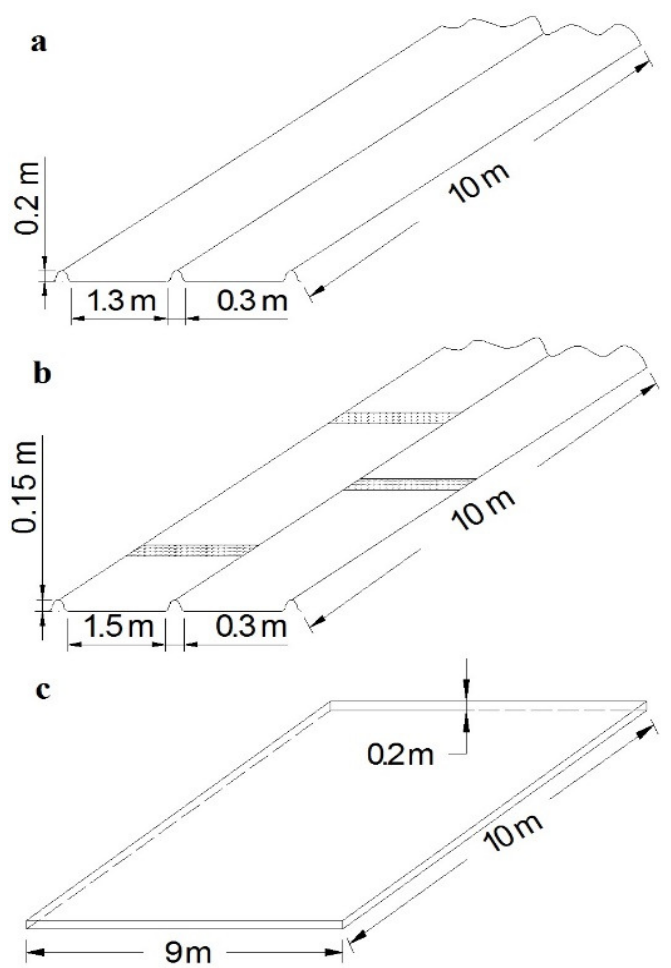

Figure 2. Schematic diagram showing (a) ridging, (b) tied-ridging and (c) basin of experimental design in the study.

\section{Crop Water Requirement}

Reference evapotranspiration $\left(\mathrm{ET}_{\mathrm{o}}\right)$ was calculated using FAO Penman- Monteith method (ALLEN et al., 1998), whistle the needed meteorological data was collected from the Northern Kordofan State meteorological station for the period 1971-2010. CROPWAT software computes ET $\left(\mathrm{mm}\right.$ day $\left.^{-1}\right)$ for each month of the growing season upon entry of the required meteorological data. Crop evapotranspiration was calculated by multiplying $\mathrm{ET}_{\mathrm{o}}$ by crop coefficients $\left(\mathrm{K}_{\mathrm{c}}\right) . \mathrm{K}_{\mathrm{c}}$ was taken for two seasons as $0.4,1.1$, and 0.7 for initial, development and late season stages, respectively as suggested by DOORENBOS et al. (1986). The amount of water added to each plot per irrigation is calculated by multiplying the depth of SI with the plot area and finally divided by the overall irrigation system efficiency taken as $60 \%$ (STERN, 1979). The FAO Penman- Monteith to estimate $\mathrm{ET}_{\mathrm{o}}$ can be written as follows:

ETo $=\frac{0.408 \Delta\left(R_{n}-G\right)+\gamma \frac{900}{\mathrm{~T}+273} U_{2}(e s-e a)}{\Delta+\gamma\left(1+0.34 U_{2}\right)}$

Where:

$\mathrm{ET}_{\mathrm{o}}$ : reference evapotranspiration $\left(\mathrm{mm} \mathrm{day}^{-1}\right), \mathrm{R}_{\mathrm{n}}$ : net radiation at the crop surface $\left(\mathrm{MJ} \mathrm{m}^{-2} \mathrm{day}^{-1}\right), \mathrm{G}$ : soil heat flux density $\left(\mathrm{MJ} \mathrm{m}^{-2}\right.$ day $\left.^{-1}\right)$, T: mean daily air temperature $\left({ }^{\circ} \mathrm{C}\right), \mathrm{U}_{2}$ : wind speed at $2 \mathrm{~m}$ height $\left(\mathrm{m} \mathrm{s}^{-1}\right), \mathrm{e}_{\mathrm{s}}$ : saturation vapour pressure $(\mathrm{kPa}), \mathrm{e}_{\mathrm{a}}$ : actual vapour pressure $(\mathrm{kPa}), \mathrm{e}_{\mathrm{s}}-\mathrm{e}_{\mathrm{a}}$ : saturation vapour pressure deficit $(\mathrm{k} \mathrm{Pa}), \Delta$ : slope of the vapour pressure curve $\left(\mathrm{k} \mathrm{Pa}^{\circ} \mathrm{C}^{-1}\right), \gamma$ : psychrometric constant $\left(\mathrm{k} \mathrm{Pa}^{\circ} \mathrm{C}^{-1}\right)$.

\section{Water Use Efficiency (WUE)}

According to OUDA et al. (2007) water use efficiency $\left(\mathrm{kg} \mathrm{m}^{-3}\right)$ was determined by dividing grain yield $\left(\mathrm{kg} \mathrm{ha}^{-1}\right)$ to the consumptive use $\left(\mathrm{m}^{3} \mathrm{ha}^{-}\right.$ $\left.{ }^{1}\right)$.

WUE $=\frac{\text { sorghum grain dry woight }\left(\mathrm{lg} \mathrm{ha} \mathrm{a}^{-1}\right)}{\text { consumptive use of water }\left(\mathrm{m} \mathrm{ha}^{-8}\right)}$

\section{Plant Material and Cultural Practices}

The soil was prepared by chisel plough followed by disc plough and leveler. Sorghum crop was planted on $7^{\text {th }}$ July in two cropping seasons of 2012 and 2013. The crop was planted flat on rows and hills at a seed rate of $60 \mathrm{~kg} \mathrm{ha}^{-1}$. The rows were arranged along the slope and nitrogen fertilizer was applied to the plots at a rate of $200 \mathrm{~kg} \mathrm{ha}^{-1}$ at sowing and mid-season.

Soil Moisture Content (SMC \%)

Soil samples were taken from depth of $0-20$ $\mathrm{cm}$ (top layer) at three locations per plot during two cropping seasons of 2012 and 2013. The effective root zone depth of sorghum in sandy loam soil is assumed as $0.4 \mathrm{~m}$. The soil moisture content expressed by percentage on dry basis was 
determined by gravimetric method (MICHAEL, 1998).

\section{Plant Growth Parameters and Yield Components}

Days to $50 \%$ flowering, direct counting of flowering heads was made using the one-half meter quadrant. Three samples were taken randomly from each plot. The percentage of flowering plants was taken using the following relation:

$\%$ flowering plants $=[$ Number of flowering plants/total number of plants] $\times 100$

Fresh matter weight productivity, three areas $1 \mathrm{~m} \times 1 \mathrm{~m}$ each were selected randomly from each plot and the plants in those plots were cut at the end of both seasons. The plants were then tied in bundles, labeled and weighed to obtain the green forage productivity. Dry matter productivity, the bundles which were used for the weight of the fresh matter determination were sun dried for ten days and then reweighed to obtain the dry forage productivity. The fresh and dry matter productivity weight was expressed as $\mathrm{kg}$ per ha. Fifteen plants were selected randomly from each plot for measuring the grains were threshed and weighed to record grain yield $\left(\mathrm{kg} \mathrm{ha}^{-1}\right)$.

\section{Statistical Analyses}

The data was analyzed by (ANOVA), using SPSS software (version 16.0, SPSS Inc., Chicago, IL, USA). Significant differences between means were considered at $\mathrm{P} \leq 0.05$, while the treatments means were compared by Duncan's Multiple Range Test (DMRT).

\section{RESULT AND DISCUSSION}

\section{Crop Water Requirement (CWR)}

Using the FAO-Penman-Monteith formula and the (CROPWAT, 1998) software, the reference crop evapotranspiration $\left(\mathrm{ET}_{\mathrm{o}}\right)$ were $8.5,7.8,7.9$ and $7.7 \mathrm{~mm}$ day $^{-1}$ for July, August, September and October, respectively. Hence, the sorghum CWR $\left(\mathrm{ET}_{\mathrm{o}} \times \mathrm{Kc}\right)$ are given in Table 2. The results revealed that the CWR of sorghum increased gradually with the plant development, starting with $3 \mathrm{~mm} \mathrm{day}^{-1}$ at the initial stage reaching peak to 9 $\mathrm{mm}$ day $^{-1}$ late stage and then decreased to $6 \mathrm{~mm}$ day at the late growing stages. This result may be attributed to the crop coefficient value $(\mathrm{Kc})$ which varied with the crop growth stages. The calculated seasonal CWR for sorghum is $397 \mathrm{~mm}$ (Table 2) and consistent with the results of Doorenbos and Pruitt (1977) that reported a range of 300- $650 \mathrm{~mm}$. Another investigation done by ADIL et al. (2012) on seasonal CWR of rain-fed sorghum found that the value range between 511.4 and $542.4 \mathrm{~mm}$.

\section{Soil Moisture Content}

A significant improvement of yield components of rain-fed sorghum is usually constrained by conservation of soil moisture in crop root zone depth. Figure 3 shows the average soil moisture content (SMC) in during cropping season in 2012 and 2013. Results showed that, the SMC ranged 10.59 to 3.84 and 11 to $4.38 \%$ in the first and second seasons, respectively. $\mathrm{T} 1_{\mathrm{w}}$ showed the highest values of SMC in both the seasons compared to control without SI $\left(\mathrm{T} 4_{\mathrm{o}}\right)$ that showed the lowest values. This might be attributed to the fact that $\mathrm{T} 1_{\mathrm{w}}$ has the ability to increase the soil moisture holding capacity by increment soil porosity and infiltration rates, and reducing the surface runoff by providing surface roughness or microrelief which assist to temporary storage of rain water, thus providing more time for infiltration, in the vicinity of plant roots which lead to optimum soil aeration and moisture level (GARDNER et al., 1999; WALTER et al., 2006). So far, however, the supplemental irrigation is generally considered an effective way to reduce drought, water stress and is therefore ensuring water storage in the soil of time need. Our data is consistent with other studies that showed low value of SMC obtained by the $\mathrm{T} 4_{\mathrm{o}}$ treatment which may be due to high runoff and reduced infiltration as a result of the formation of soil sealing (OWEIS; HACHUM, 2012; HULUGALLE et al., 1990). 


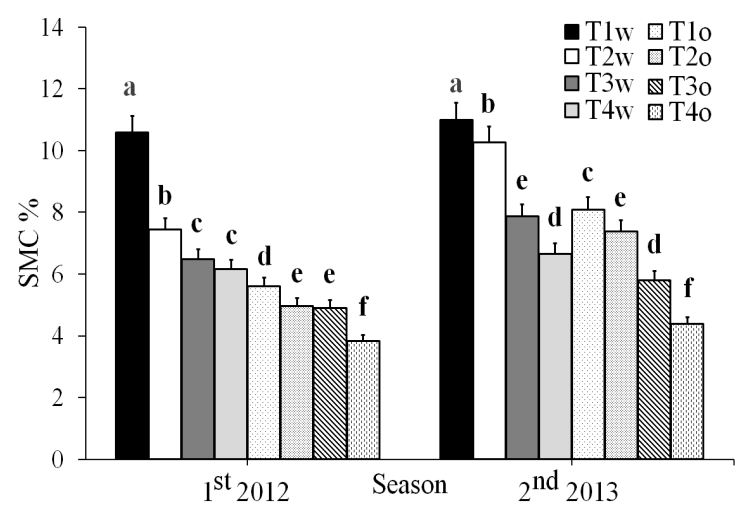

Figure 3. Soil moisture content as affected by water harvesting and supplemental irrigation (SI).

Note: $\mathrm{T} 1_{\mathrm{w}}$, tied ridging with supplemental irrigation; $\mathrm{T} 2_{\mathrm{w}}$, ridging with supplemental irrigation; $\mathrm{T} 3_{\mathrm{w}}$, basin with supplemental irrigation; $\mathrm{T} 4_{\mathrm{w}}$, control with supplemental irrigation; $\mathrm{T} 1_{\mathrm{o}}$, tied ridging without supplemental irrigation; $\mathrm{T} 2_{\mathrm{o}}$, ridging without supplemental irrigation; $\mathrm{T} 3_{0}$, basin without supplemental irrigation; $\mathrm{T} 4_{0}$, control without supplemental irrigation.

\section{Applied of Supplemental Irrigation}

The amount of supplemental irrigation (SI) applied (mm per irrigation) is shown in (Table 3) for seasons 2012 and 2013. The total amount of SI water applied was 493 and $522 \mathrm{~mm}$ for season 2012 and 2013, respectively. The amount of SI applied in season 2013 was higher than 2012 due to higher contribution of rainfall in 2012 than in 2013. Table 3 shows the amount of SI per irrigation in $\mathrm{m}^{3} \mathrm{ha}^{-1}$ for the two seasons of 2012 and 2013. The result showed that the highest amount of water applied was $992 \mathrm{~m}^{3} \mathrm{ha}^{-1}$ in the sixth and seventh irrigations. This highest amount of water applied to irrigate sorghum against highest CWR during that crop growth stage attributes to climatic factors, such as low and erratic rainfall, low humidity and high temperature (BOTHA et al., 2003).

Table 2. Crop water requirements (CWR) of sorghum.

\begin{tabular}{ccccc}
\hline Plant growth stage & $\mathrm{K}_{\mathrm{c}}$ & $\mathrm{ET}_{\mathrm{o}}$ & CWR mm day $^{-1}$ & CWR per irrigation $(\mathrm{mm})$ \\
\hline \multirow{3}{*}{ Initial stage } & 0.4 & 8.5 & 3 & 27 \\
& 0.4 & 7.8 & 3 & 25 \\
& 0.4 & 7.8 & 3 & 25 \\
& 0.4 & 7.8 & 3 & 25 \\
\hline Development stage & 1.1 & 7.8 & 9 & 69 \\
& 1.1 & 7.8 & 9 & 69 \\
\hline Late stage & 0.7 & 7.8 & 6 & 69 \\
Total & 0.7 & 7.8 & 6 & 44 \\
\hline
\end{tabular}

Note: $K_{\mathrm{c}}$, crop coefficient; $\mathrm{ET}_{\mathrm{o}}$, reference evapotranspiration. CWR: crop water requirements; SI: supplemental irrigation.

Table 3. Supplemental irrigation $(\mathrm{mm})$ application in two cropping seasons.

\begin{tabular}{|c|c|c|c|c|c|c|c|c|c|c|}
\hline Year & & & & & 2012 & & & & & \\
\hline Irrigation No. & *1 1 & 2 & 3 & 4 & 5 & 6 & *7 7 & 8 & 9 & Total \\
\hline CWR per irrigation & * 27 & *25 & 25 & 25 & 69 & 69 & *69 69 & 44 & 44 & 397 \\
\hline Effective rainfall (mm) & 0 & 0 & 9 & 24 & 8 & 0 & 0 & 0 & 12 & 53 \\
\hline SI water needed (mm) & 27 & 25 & 16 & 1 & 61 & 69 & 69 & 44 & 32 & 345 \\
\hline SI water applied (mm) & 38 & 36 & 23 & 1 & 87 & 99 & 99 & 63 & 46 & 493 \\
\hline Year & & & & & 201. & & & & & \\
\hline Irrigation No. & ${ }^{*} 1$ & 2 & 3 & 4 & 5 & 6 & *7 7 & 8 & 9 & Total \\
\hline CWR per irrigation & * 27 & 25 & 25 & 69 & 69 & 69 & *69 & 44 & 44 & 397 \\
\hline Effective rainfall (mm) & 0 & 0 & 13 & 0 & 19 & 0 & 0 & 0 & 0 & 32 \\
\hline SI water needed (mm) & 27 & 25 & 12 & 25 & 50 & 69 & 69 & 44 & 44 & 365 \\
\hline SI water applied (mm) & 38 & 36 & 17 & 36 & 71 & 99 & 99 & 63 & 63 & 522 \\
\hline
\end{tabular}

Note: Irrigation numbers 1,2 and 7 were given to all treatments; Effective rainfall=0.70 of rainfall; irrigation efficiency=0.60; *, Highest CWR; CWR, crop water requirement; SI, supplemental irrigation. 


\section{Days To 50 Percent Flowering}

As can be seen from (Figure 4) the Days to $50 \%$ percent flowering (DFPF) was affected by WHTs and SI. In the first season, DFPF ranged between 54.17 and 46.1, while in the second season ranged between 115 and $84 . \mathrm{T} 1_{\mathrm{w}}$ was superior in DFPF in the first (54.17) and the second (115) seasons, which was significantly different from other treatments. The lowest DFPF was experienced from $\mathrm{T} 4_{\mathrm{o}}$ (46.1 and 84 ) recorded in the first and the second seasons. No significant differences were noticed for $\mathrm{T} 2_{\mathrm{o}}$ in the first season and from $\mathrm{T} 2_{\mathrm{o}}$ and $\mathrm{T} 3_{\mathrm{o}}$ in the second season. The highest number of DFPF which was recorded by $\mathrm{T} 1_{\mathrm{w}}$ may be attributed to the increase amount of water available in the root zone in turns increases moisture content, which encourages vegetative growth and delayed flowering. While the lowest number of DFPF recorded by $\mathrm{T} 4_{0}$ may be attributed to root zone water deficit and low soil moisture storage. These results also confirmed by (HASSAN et al., 2012). In this study the number of days to $50 \%$ flowering was shortened by $\mathrm{T} 4_{0}$ application. Similar results were obtained by ADIL et al. (2012) who indicated that flowering of sorghum was hastened by short soil moisture content; which explains their responsiveness to water.

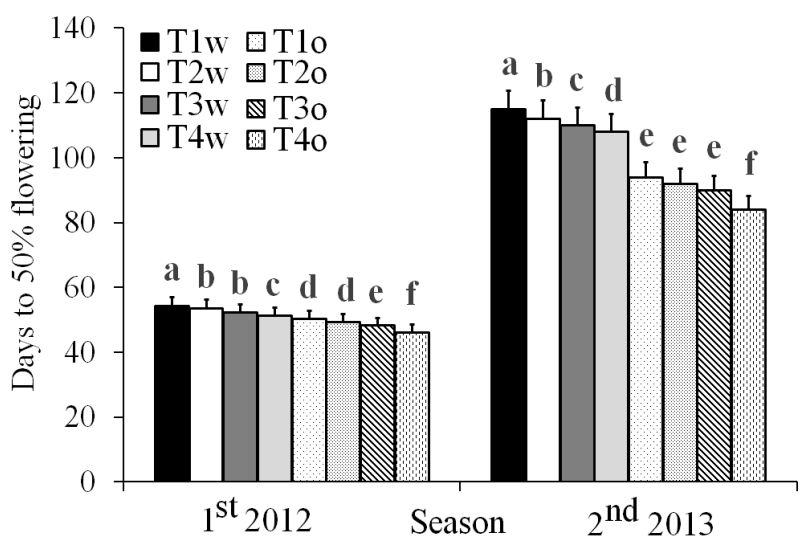

Figure 4. Effects of water harvesting techniques and supplemental irrigation on days to fifty percent flowering.

\section{Fresh and Dry Matter Productivity of Sorghum}

In condition of WHTs, fresh and dry mass content is significantly higher $(\mathrm{p}<0.01)$ in WHTs with SI corresponded to WHTs without SI. SI showed significantly different effect $(\mathrm{p} \leq 0.05)$ on fresh matter productivity in season 2012 and highly significant effect $(\mathrm{p} \leq 0.01)$ in season 2013. Meanwhile WHTs showed highly significant effect $(\mathrm{p} \leq 0.01)$ on fresh mass productivity in the two seasons and the interaction between SI and WHTs showed no significant effect in the first season and highly significant effect $(p \leq 0.01)$ in the second season. The means of results of fresh matter productivity of sorghum as affected by SI and WHTs are shown in (Figure 5a) for the two seasons. The highest values of fresh matter were obtained under WHTs and SI by $\mathrm{T}_{\mathrm{w}}, 22,500$ and $23,300 \mathrm{~kg}$ $\mathrm{ha}^{-1}$ for the first and second seasons respectively. Rajan et al. (2004), stated that the fresh weight has an increased trend with increased irrigation water. No significant difference was observed between $\mathrm{T} 1_{\mathrm{w}}$ and basin with SI $\left(\mathrm{T}_{\mathrm{w}}\right)$ in the first season but a significant difference was observed in the second season. On the other hand the lowest values were obtained by $\mathrm{T}_{0}, 4900$ and $1700 \mathrm{~kg} \mathrm{ha}^{-1}$ for the first and second season, respectively. The treatment showed no significant difference from $\mathrm{T} 2_{\mathrm{o}}$ and $\mathrm{T} 3_{\mathrm{o}}$ in the first season and showed significant difference from the other treatments in the second season. This result may be attributed to the fact that the $\mathrm{T} 1_{\mathrm{w}}$ gave the highest plant density and this was clearly reflected in increasing the fresh matter productivity of sorghum. These results agreed with Adil et al. (2012) results that reported the highest plant density gave the highest sorghum productivity.

As general dry matter increase with SMC and available absorbed water in root zone, thus was ensure the advantage crops growth (vegetation stage, flowering and maturity). SI showed significant difference $(\mathrm{p} \leq 0.05)$ in season 2012 and highly significant difference in season 2013. The results of dry matter productivity of sorghum as affected by SI and WHTs were shown in (Figure 5b) for the two seasons. The highest values were recorded by $\mathrm{T} 1_{\mathrm{w}} 9900$ and $10800 \mathrm{~kg} \mathrm{ha}^{-1}$ for the second and first seasons, respectively. The treatment significantly differs from all other treatments in season 2013. Undoubtedly, improvement of the dry matter was attributed to alleviation of water stress, but the occurrence of supplemental irrigation caused flooding and suppressed the beneficial impact of irrigation. Meanwhile there was no significant 
difference from $\mathrm{T} 3_{\mathrm{w}}$ in season 2012. On the other hand the lowest values reviled by $\mathrm{T} 4_{0} 1100$ and $1700 \mathrm{~kg} \mathrm{ha}^{-1}$ for the first and second seasons, respectively. The treatment showed no significant difference from $\mathrm{T} 1_{0}, \mathrm{~T}_{3}$ and $\mathrm{T} 2_{\mathrm{o}}$ in the first season 2012; while it was significantly different from $\mathrm{T} 1_{\text {o }}$ and $\mathrm{T}_{\mathrm{o}}$ in the second season. The lower values of dry matter productivity obtained by $\mathrm{T}_{\mathrm{o}}$ as compared with the other treatments may be attributed to the effect of water stress. This stressed reduction in dry matter affected negatively forage and protein yields which results of the balance between the absorption and the transpiration (BACELAR et al., 2007).
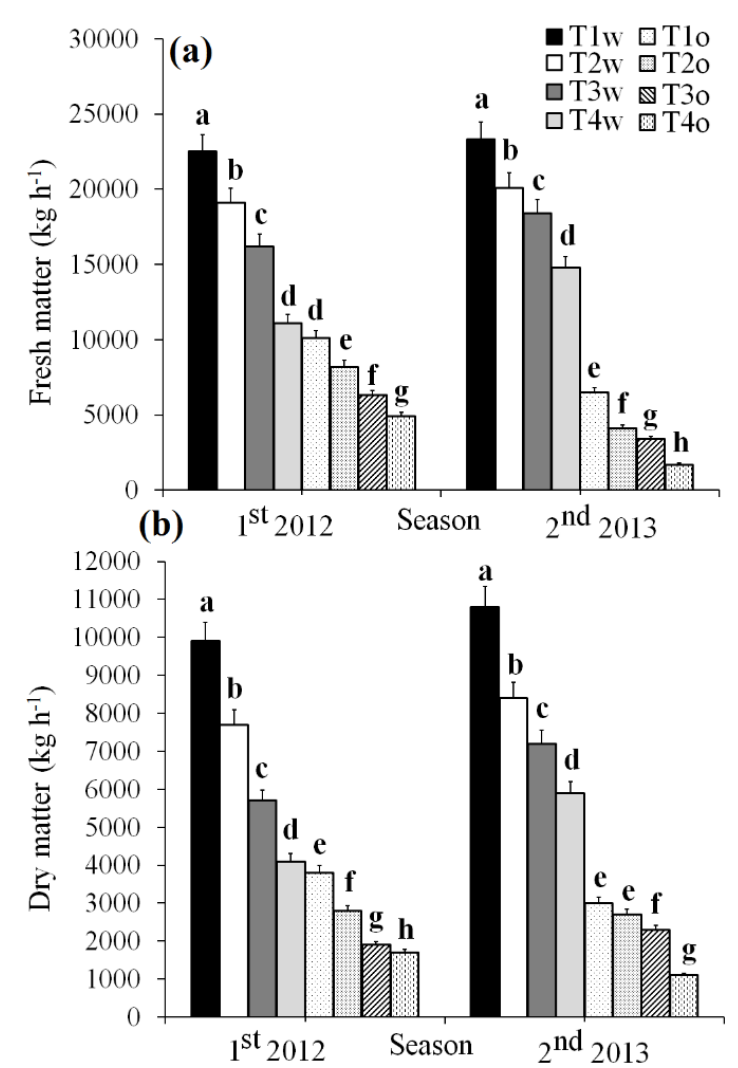

Figure 5. Fresh and dry matter productivity as affected by water harvesting techniques and supplemental irrigation.

\section{Yield Productivity}

Average grain productivity of Sorghum was affected by SI and WHTs as shown in (Figure 6) for the two seasons. The highest productivity of 3850 and $4760 \mathrm{~kg} \mathrm{ha}^{-1}$ was obtained by $\mathrm{T} 1_{\mathrm{w}}$ for first and second seasons, respectively. Insignificant differences $(\mathrm{P} \leq 0.05)$ were observed between $\mathrm{T} 1_{\mathrm{w}}$ and $\mathrm{T} 4_{\mathrm{w}}$ in the first season, however, significant differences $(\mathrm{P} \leq 0.05)$ were observed in the second season. The lowest productivity of 840 and $830 \mathrm{~kg}$ $\mathrm{h}^{-1}$ was obtained by $\mathrm{T} 4_{\mathrm{o}}$ in first and second seasons, respectively. For $\mathrm{T}_{2}$ and $\mathrm{T} 3_{\mathrm{o}}$ in the, there was insignificant difference in the first season but showed significant difference in the second season.

It is elucidated that, the parameters bound to the efficiency of the use of water and have a determining agronomic significance for the production of the sorghum. This result could be attributed to the fact that the $\mathrm{T} 1_{\mathrm{w}}$ gave the highest plant density by the concentrated organic matter and fertilizer present near the soil surface in the tiedridge, which was found to be 0.54 and $1.2 \%$ for the first and second season, respectively. This, clearly reflected in increasing the grain productivity of sorghum (TABO et al., 2002; REDDY et al., 2011). The lowest values may be refer to that water deficits affected grain yield primarily through effect on number of grain when it occurred during the period from emergence to time after floral initiation (ABDEL-MOTAGALLY, 2010). Succinctly, it is concluded that SI will help to put more land under cultivation, increase productivity and decrease the deficit of food in NKS leading to better utilization of the natural resources. 


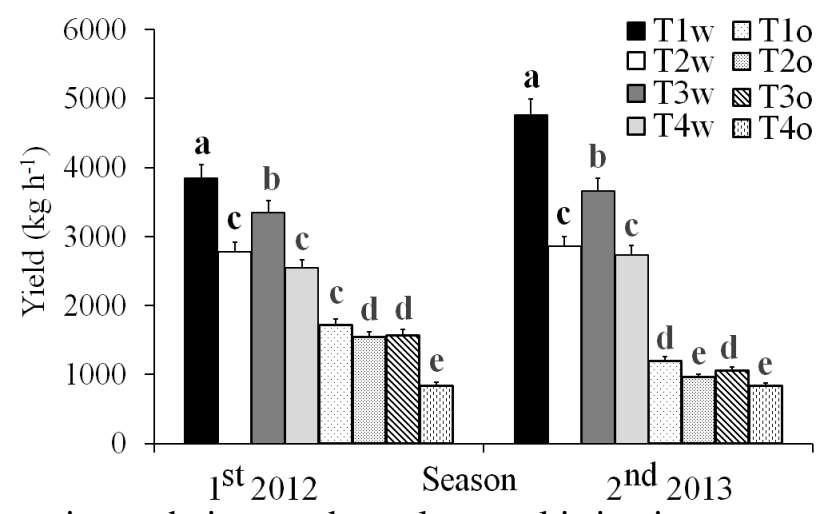

Figure 6. Effect of water harvesting technique and supplemental irrigation on sorghum grain productivity.

\section{Sorghum Water Use Efficiency (WUE)}

Actually any practice that improves soil water conservation in soil layer reflected in the total crop water use and grain yield but the WUE quite differed. However, there are many reasons for the resulting differences in WUE and as it was evident from (Figure 7) that WUE was increased due to higher utilization of water in the root zone. That possibly because of relatively due to high rainfall season as corresponded to low rainfall season when the water supply is limited and transpiration might be increased relative to other pathways of loss (OWEIS; HACHUM, 2012). The WUE was affected by WHTs and SI (Figure 7). The WUE ranged between 0.71 and $0.21 \mathrm{~kg} \mathrm{~m}^{-3}$ in the first season and between 0.86 and $0.27 \mathrm{~kg} \mathrm{~m}^{-3}$ in the second season. $\mathrm{T} 1_{\mathrm{w}}$ showed the highest value of the WUE in the first (0.71) and the second (0.86) seasons. The results are not significantly different $(\mathrm{P} \geq 0.05)$ between $\mathrm{T} 4_{\mathrm{w}}$ and $\mathrm{T} 2_{\mathrm{w}}$ and also $\mathrm{T} 1_{\mathrm{o}}, \mathrm{T} 2_{\mathrm{o}}$ and $\mathrm{T}_{\mathrm{o}}$ are not significantly differed in the both season. $\mathrm{T} 4_{\mathrm{o}}$ showed the lowest value of WUE in the first $(0.21)$ and the second season $\left(0.27 \mathrm{~kg} \mathrm{~m}^{-3}\right)$. T4。 results were not significantly different from $\mathrm{T} 2{ }_{\mathrm{o}}$ in two seasons. The lowest values of the WUE recorded by $\mathrm{T} 4_{\mathrm{o}}$ treatment this may be attributed to the fact that the crop was subjected to water stress throughout the growth season. Similar results were obtained by, ADIL et al. (2012). The availability of soil water and water conveying systems is resulting in increased use of supplementary irrigation (SI) as well as improving overall WUE. The combination of WHT systems supported by SI greatly improves biomass production as well as grain production by allowing for enhanced root zone storage capacity (STROOSNIJDER et al., 2012). The sorghum yield was significantly enhanced when TR combined with SI. Singh et al. (2010), reported that SI is efficient approach to increase the water use efficiency complementing the rainfall deficiency. Xiao et al. (2007) found that supplemental irrigation led to increment in yield of wheat by $11.0 \mathrm{~kg} \mathrm{~mm}^{-1} \mathrm{ha}^{-1}$ under rain-fed this reflected in high water-use efficiency. Johan et al. (2002) investigated the application of supplemental irrigation In Burkina Faso, the result showed that use of SI increasing water use efficiency from 0.9 to $1.2 \mathrm{~kg} \mathrm{ha}^{-1} \mathrm{~mm}^{-1}$ due to enhancing the soil water holding capacity. Similar results were observed by Li et al. (2000) on maize, who found that supplemental irrigation increase yield of 20 to $88 \%$, corresponding to $60 \mathrm{~kg}$ $\mathrm{ha}^{-1} \mathrm{~mm}^{-1}$ WUE. Hence, when dealing with crop production in areas suffering of rainwater shortage and drought stress using of RWH along with SI should be consider since they are effective tools in order to improving yield and WUE. 


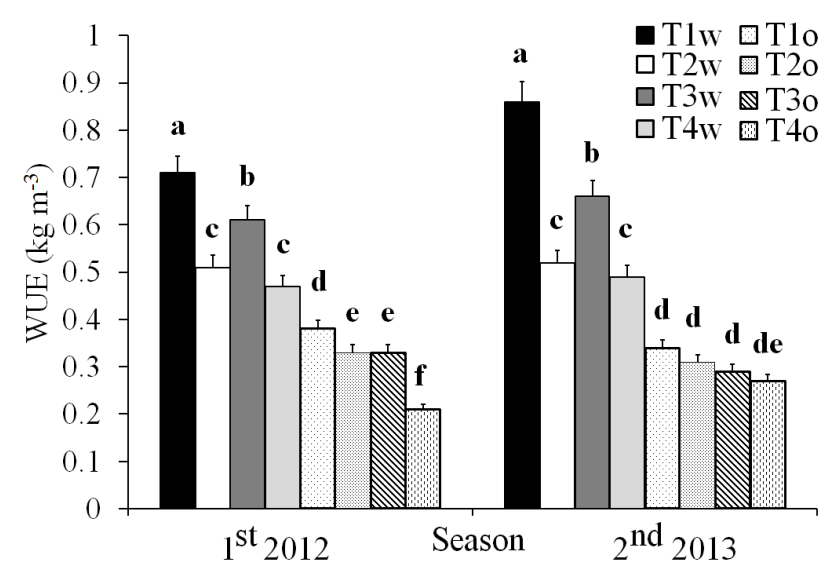

Figure 7. Effect of water harvesting technique and supplemental irrigation on sorghum water use efficiency.

\section{CONCLUSIONS}

The studies on WHTs combined with SI practices are limited, however, these techniques directly affected the moisture content, sorghum yield and yield components. Our data indicated some evidence for the good performance of the tiedridging (TR) linked with the SI in terms of enhancing yield and water use efficiency could be unlimited, especially at semi-arid area. Reduced soil percolation, increased water availability, improved root growth performance could result in higher yield productivity. Using the SI, offers a great potential for enhanced yield productivity particularly in arid and semi as well as sub-humid region that have high rainfall variation interfere with drought spell, thus SI is a key management tool, still under-used, for sustaining yield potential and water productivity. Conclusively, adding water it seems to be superior adapted and could be recommended to produce a high growth and grain yield $t$ ha $^{-1}$ with high water use efficiency and more crop per drop of water could be achieved at NKS.

RESUMO: O sorgo é um alimento importante e uma cultura de cereais multi-propósito dominante no Sudão. Sua produção é influenciada pelo teor de água disponível no solo da planta na plantação e na precipitação da estação de crescimento. Foram realizadas séries de experimentos de campo para estudar a potencialidade do uso da água do sorgo usando diferentes técnicas de colheita de água (WHT - water harvesting techniques) e irrigação suplementar (SI supplemental irrigation). O teor de umidade do solo (SMC - Soil moisture content), o rendimento de grãos e a eficiência do uso da água (WUE - water use efficiency) de sorgo foram calculados nos anos de 2012 e 2013. Os resultados mostraram que o WHT e SI afetaram os parâmetros SMC, crescimento e produtividade do sorgo. Os resultados também foram indicados que o empate com SI (T1w) produziu os maiores valores de SMC, produtividade de sorgo e WUE $(10,59 \%, 3850 \mathrm{~kg}$ ha-1 e 0,71 kg m-3 na temporada 2012, respectivamente). Enquanto que na temporada 2013, os valores foram de $11 \%, 4760 \mathrm{~kg}$ ha-1 e $0,86 \mathrm{~kg} \mathrm{~m}-3$ com o mesmo arranjo mencionado acima. Conclusivamente, a WUE poderia ser promovida pela implementação de WHT como gerenciamento de água. No entanto, a SI deve considerar como fator de pivô que compense a escassez na água da chuva.

PALAVRAS-CHAVE: Sorgo. Captação de água. Eficiência do uso da água.

\section{REFERENCES}

ABDEL-MOTAGALLY, F. M. F. Evaluation of water use efficiency under different water regimes in grain sorghum (Sorghum bicolor L. Monech). World Journal of Agricultural Sciences, v. 6, n. 5, p. 499-505, 2010 .

ADIL, B. K.; HASSAN, I. M.; HAITHAM, R. E.; AMIR, B. S.; ATIF, E. I. Effects of some in-situ water harvesting techniques on soil moisture and sorghum (Sorghum bicolor (L.) Moench) production in Northern Gedaref State. Global Journal of Plant Ecophysiology, v. 2, n. 1, p. 54-66, 2012. 
AHMED, A. A.; NAGGAR, O. M. Rain Water Harvesting Concept and Techniques. Water Harvesting for Food Security and Sustainable Development. UNESCO Chair in Water Resources, Conference in Water Harvesting and the Future of Development in Sudan, Khartoum, 19-20 Aug, 2003.

Ali, A. B.; Elshaikh, N. A.; Hong, L.; Adam, A. B.; Haofang, Y. Conservation tillage as an approach to enhance crops water use efficiency. Acta Agriculturae Scandinavica, Section B-Soil \& Plant Science, v. 67, n. 3, p. 252-262, 2017.

ALLEN, R. G.; PEREIRA, L. S.; RAES, D.; SMITH, M. Crop evapotranspiration guidelines for computing crop water requirements. FAO, Rome, Italy, 1998. (Irrigation and Drainage Paper No. 56).

AYOUB, A. Land degradation, Rainfall variability and food production in the Sahelian zone of the Sudan. Land Degradation \& Development, v. 10, n. 5, p. 489-500, 1999. https://doi.org/10.1002/(SICI)1099145X(199909/10)10:5<489::AID-LDR336>3.0.CO;2-U

BACELAR, E. A.; MOUTINHO-PEREIRA, J. M.; GONÇALVES, B. C.; FERREIRA, H. F.; CORREIA, C. $M$. Changes in growth, gas exchange, xylem hydraulic properties and water use efficiency of three olive cultivars under contrasting water availability regimes. Environmental and Experimental Botany, v. 60, n. 2, p. 183-192, 2007. https://doi.org/10.1016/j.envexpbot.2006.10.003

BOTHA, J. J.; VAN RENSBURG, L. D.; ANDERSON, J. J.; KUNDHLANDE, G.; GROENEWALD, D. C.; MACHELI, M. Application of in-field rainwater harvesting in rural villages in semi-arid areas of South Africa. Water Conservation Technologies for Sustainable Dry land Agriculture in sub-Saharan Africa (WCT). Bloemfontein, South Africa, 2003.

CROPWAT for Windows; User Guide, FAO. Guidelines for computing crop water requirements. FAO Irrigation and Drainage Paper No 56. 1998, Rome, Italy, p. 300.

DOORENBOS, J.; KASSAM, A. H.; BENTVELSEN, C. L. M.; BRANSCHEID, V.; PLUSJE', J. M. G. A.; VITTENBOGANRD, G. O.; VAN DERWAL, H. K. Yield Response to Water. FAO Irrigation and Drainage Paper No. 33. 1986. FAO: Rome, Italy.

DOORENBOS, J.; PRUITT, W. O. Guide lines for Prediction of Crop Water Requirements. FAO Irrigation and Drainage Paper No. 24. 1977. FAO: Rome, Italy.

FAO/WFP. Crop and food supply assessment mission to Sudan. Special Report: Sudan, January, 2000.

GARDNER, C. M. K.; LARYEA, K. B.; UNGER, P. W. Soil physical constraints to plant growth and crop production. Land and Water Development Division. FAO: Rome, Italy, p. 96, 1999.

HASSAN, I. M.; ADIL, B. K.; HAITHAM, R. E.; AMIR, B. S.; ATIF, E. I. Performance of soil moisture retention and conservation tillage techniques as indicated by sorghum (Sorghum bicolor L. Moench.) yield and yield components. Global Journal of Plant Ecophysiology, v. 2, n. 1, p. 31-43, 2012.

HULUGALLE N. R.; KONING, J.; MATLON, P. J. Effect of rock bunds and tied ridges on soil water content and soil properties in the Sudan savannah of Burkina Faso. Tropical Agriculture, v. 67, n. 2, p. 149-153, 1990.

JIANG, Z.; LI X.; YU-JUN, M. A. Water and energy conservation of rainwater harvesting system in the Loess Plateau of China. Journal of Integrative Agriculture, v. 12, n. 8, 1389-1395, 2013.

https://doi.org/10.1016/S2095-3119(13)60553-5

MICHAEL, A. M. Irrigation: Theory and Practice. $1^{\text {st }}$ ed. VIKAS Publishing house Ltd. New Delhi, India. p. 32-76, 1978. 
MUDATENGUHA, F., J. ANENA, C. K. Kiptum and A. B. Mashingaidze. In situ rain water harvesting techniques increases maize growth and grain yield in a semi-arid agro-ecology of Nyagatare, Rwanda. International Journal of Agriculture \& Biology, v: 16, n. 5, p. 996-1000, 2014.

OUDA, A. S.; EL-MESIRY, T.; GABALLAH, S. M. Increasing Water Use Efficiency for Wheat Grown under Water Stress Conditions. Journal of Applied Sciences Research, v. 3, n. 12, p. 1766-1773, 2007.

OWEIS, T.; HACHUM, A. Supplemental irrigation, a highly efficient water-use practice. ICARDA, Aleppo, Syria. iv + 28 pp, 2012.

RAJAN, B.; KHERA, K. L.; SANJAY, A. Effect of Tillage and Mulching on Yield of Corn in the Submontaneous Rainfed Region of Punjab, India. International Journal of Agriculture and Biology, v. 6, n. 1, p. 1-3, 2004.

REDDY, B.; KUMAR, A. A.; RAMESH, S.; REDDY, P. S. Breeding sorghum for coping with climate change. In: Yadav SS, Redden B, Hatfi eld JL, Lotze-Campen H (eds) Crop adaptation to climate change. Wiley, Iowa, p. 326-339, 2011.

SALEM, H. M.; VALERO, C.; MUÑOZ, M. Á.; GIL-RODRÍGUEZ, M.; BARREIRO, P. Effect of reservoir tillage on rainwater harvesting and soil erosion control under a developed rainfall simulator. Catena, v. 113, p. 353-362, 2014. https://doi.org/10.1016/j.catena.2013.08.018

SCHEIERLING, S. M.; CRITCHLEY, W. R. S.; WUNDER, S. HANSEN, J. W. Improving water management in rainfed agriculture: Issues and options in water-constrained production systems. Water Paper, Water Anchor. The World Bank, Washington DC Water harvesting for crop production in Sub-Saharan Africa, 31, 2012.

STERN, P. H. Small Scale Irrigation: Manual of Low Water-Technology. Intermediate technology publications Ltd, and the International irrigation information Center, London), Russell press, Nottingham, p. $152,1979$.

TABO, R.; OLABANJI, O. G.; AJAWI, O.; FLOWER, D. J. Effect of plant population density on the growth and yield of sorghum varieties grown on a vertisol. African Crop Science Journal, v. 10, n. 1, 31-38, 2002. https://doi.org/10.4314/acsj.v10i1.27555

WALTER, M.; DAVID, L.; STEVE, T. Soil-water conservation and rainwater harvesting strategies in the semiarid Mzingwane Catchment, Limpopo Basin, Zimbabwe. Physics and chemistry of the Earth, Parts A/B/C, v. 31, n. 15, 893-900, 2006.

XIAO, G.; ZHANG, Q.; XIONG, Y.; LIN, M.; WANG, J. Integrating rainwater harvesting with supplemental irrigation into rain-fed spring wheat farming. Soil \& Tillage Research, v. 93, 429-437, 2007.

SINGH, R.; KUNDU D.; BANDYOPADHYAY K. Enhancing agricultural productivity through enhanced water use efficiency. Journal Agricultral Physics, v. 10,1-15, 2010.

JOHAN, R.; JENNIE B.; PATRICK F. Rainwater management for increased productively among small-holder farmers in drought prone environments. Physics and chemistry of the Earth, Parts A/B/C, v. 27, 949-959, 2002.

LI, F.; COOK, S.; GEBALLE G.T.; JR BURCH W.R. Rainwater harvesting agriculture: An integrated system for water management on rainfed land in China's semiarid areas. AMBIO, v. 29, 477-483, 2000. 